\title{
Decolonial Encounters and the Geopolitics of Racial Capitalism
}

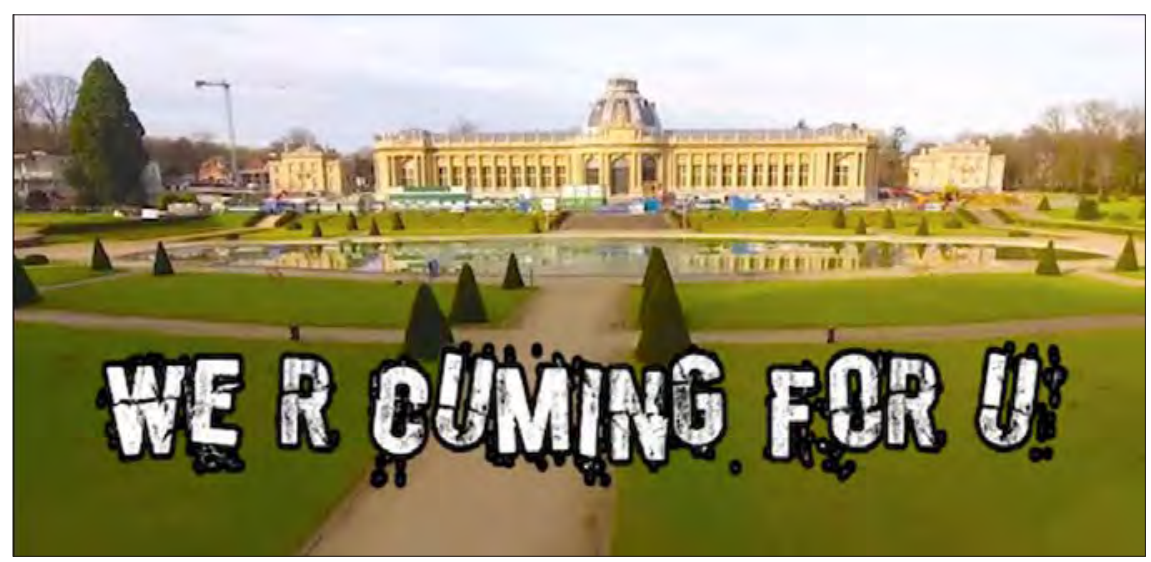

7 his conversation started in the summer of 2018 at the first Balkan Society for Theory and Practice workshop that took place in Prizren, Kosova. Scholars, activists, and artists came together to engage in a very much needed debate about the past, present, and future of anticapitalist politics, feminism, queer and trans studies, critical race theory, postcolonial and decolonial critique in the context of the post-socialist Balkan countries and former Eastern Europe. The idea for this tri-logue came out of late night and early morning conversations based on common concerns and collaborations that have taken various forms through years of exchange and engagement with one another. What follows is a discussion among the three of us based on the questions posed in the open call for this special issue Breaking with Transition: Decolonial and Postcolonial Perspectives in Eastern Europe. To articulate some critical points, we find it necessary to rethink the conflicts and tensions and to envisage important analytical turns and political tactics within our ongoing struggles against turbo-racializing capitalism.

Photo: "Fuck the Fascism" Brussels Conspiracy Gathering, 2018; MariaBasura and Jorge Benavides, "Terrorismo Teatral Migrante" group; https://fuckthefascism.noblogs.org 
1. To take a political stance and further elaborate the decolonial critique about postsocialism and former Eastern Europe, we think it is necessary to bring together some introductory lines on what it means to speak about decoloniality in Eastern Europe and what decoloniality means for the post-socialist contemporary context. Where are we now and where do we stand?

Tjaša Kancler: To begin elaborating a double critique I propose the following thesis: post-socialism is not at all postcolonial. As Neda Atanasoski argues, "if post-socialism is relegated to periodizing a particular moment of regional transition that at once affirms the death of socialism and consigns it to an ideological formation inferior to Western modernity and universality, it particularizes what is actually a global condition in which the West situates the universal claims of human rights, freedom, democracy, that underwrite its global violence" (Atanasoski 2013, 26). This means that we have to analyse the entanglement of modernity, colonialism, and capitalism to understand the East (former Eastern Europe) in condition of coloniality in relation to the West. This requires taking into account the imitation of Western modernity by Eastern Europe, with racism at its core. Thus, while the Eurocentric critique of capitalism focuses on economic relations over other social, political, and cultural ones, the decolonial turn after 1989, without negating the continuous accumulation of capital on the global scale, class divisions and exploitation, points to the conflict through de/coloniality.

Aníbal Quijano, one of the founding members of the research group Modernity/Coloniality/Decoloniality, introduced a new concept named "coloniality" as the indispensable underside of modernity, which began in the $15^{\text {th }}$ century and continues today. He defines coloniality as a matrix of power that operates through four interrelated domains: the control of economy, the control of authority, the control of gender and sexuality, and the control of subjectivity and knowledge (Mignolo 2008). Quijano conceptualized the intersections of multiple, heterogeneous, global hierarchies, and forms of domination and exploitation: racial, sexual, gendered, political, economic, spiritual, and linguistic. Emphasizing its structural, constitutive, and not derivative relations, by claiming intersectionality, these are in fact analytical methods introduced previously by the Black feminists (Combahee River Collective, Kimberlé Crenshaw, Audre Lorde, and Patricia Hill Collins, among others) and developed further by and with feminists of color (e.g., Chela Sandoval, Chandra Mohanty, Gloria Anzaldúa, Cherríe Moraga) to point to their historical, theoretical, and practical exclusions. Interlacing these lines of analysis with those of the global capitalist power elaborated by Quijano, María Lugones introduced a concept provisionally called "the modern/colonial gender system" to make visible the instrumentality of the modern/colonial gender system in the subjugation of people of color in all areas of existence (Lugones 2008). Or, to refer to Gržinić's analysis, the implications of racism are deeply related to class and gender (Gržinić 2013). 
Decolonial ways of sensing-thinking-acting are a radical attempt to de-universalize, de-naturalize and dismantle capitalist/colonial, patriarchal, political, institutional, class, ethno/racial, sexual and gender border structures that operate in multiple ways locally and globally today.

Marina Gržinić: In order to approach the decolonial we have to first look to post-socialism and the post-colonial. First, because they precede the decolonial and also because both bear the prefix post. But to simply equate them is false parallelism; post-socialism is a condition of the whole territory of former Eastern Europe that denotes a transitional moment in the 1990s, after the fall of the Berlin wall in 1989. For post-socialism, the referent is socialism that provided strong support to decolonization struggles after the WWII, which supported the idea of the non-aligned movement, building ties with Africa and the Middle East in the time of the Cold war.

In such a context, in the period of post-socialism in the 1990s that was heavily pressed by the West to forget its socialist past (and to cut any relation with socialism), we recognize other important counter positions. In the context of ex-Yugoslavia, the LGBTQ movement that organized and critically intervened in Slovenia, then the media technology and internet possibilities opened a production of independent projects that tackled in the time of the Balkan war in the 1990s important cultural and media reflections on the war. During the 1990s, in the period of post-socialism in former Yugoslavia, I completed a doctoral dissertation, which I later published as a book titled, In a Line for Virtual Bread (Gržinić 1996). In this text, I brought together post-colonial theory (Trinh Minh-ha), cyberfeminism (Donna Haraway), and the war in the Balkans to question the position of former Eastern Europe. My thesis was that the critique of post-socialism or the post-socialist condition and the post-colonial theory have, primarily on the cultural level, powerfully intervened on the state of things.

Decoloniality is, on the other side, connected with changes that were brought by neoliberal global capitalism. Neoliberal global capitalism dismisses the space of culture as a place of a radical critique. Neoliberal global capitalism, which I argue fully emerges in 2001 after the events of 9/11, introduced war as a direct machine for profit and death as its currency and vomits culture in front of our eyes as something completely subjugated to the socalled cultural industry. Neoliberal global capitalism has advanced with the death of thousands and more. To do this, it engages heavily in discrimination, separation, and ghettoization. We should not forget that the 1990s is the decade of multiculturalism, while the $21^{\text {st }}$ century overtly despises the "Other." The latter is produced persistently through heavily racialized mechanisms. This is manifest in a myriad of hyper discrimination processes.

I want to emphasize here a genealogy of racism that bypasses individual racism, and that shows itself in the form of insidious, visible and non-visible processes, procedures, conditions that produce through the category of "race" systematic, permanent and unquestioned marginality, inequality and 
discrimination. A race is only projected onto people because of their color, culture, or ethnic origins. So the regime of whiteness is privileged and unquestioned from the very start, because "white" is seen "colourless" and "neutral." This genealogy of racism presents itself historically as scientific racism, institutional racism, social racism and finally structural racism working on every level of capitalist societies. In this relation, the term racialization designates and emphasizes the very process of discrimination that is ideological, systemic and material at work within different racisms. Farhad Dalal stated that "racialization is the very complex and contradictory process through which groups come to be designated as being of a particular 'race' and on that basis subjected to differential and unequal treatment" (Dalal 2002).

At this point, the most interesting element provided by decolonial theory is, as already emphasized by Kancler, the colonial matrix of power or coloniality of power. Cetshwayo Zindabazezwe Mabhena in 2017 recuperates vividly what this is:

A colonial power matrix is in place that functions through governments of the world, big businesses and other entities. The interconnectedness and networking of these organisations to make a world system is what is called the world order, how the world works. When he coined the term 'coloniality of power' in 2000 Peruvian sociologist Anibal Quijano did not really invent anything new but came up with a fresh way of understanding a colonial and imperial problem that had haunted thinkers and leaders of the Global South for centuries. By the coloniality of power and colonial power matrix decolonial theorists have come to mean the structures and institutions of power, control and hegemony that emerged with the modern world of colonialism starting in 1492 and are still at large (Mabhena 2017).

Returning to the European context, we must ask what economic and cultural shifts occurred as a result of 2001? I argue that Europe has at least two types of capitalism. Following Paul Preciado, there is a hot (punk) capitalism that has primarily developed in the "former" West and the first capitalist world. The importance of hot capitalism is mostly semiotically-technologically organised. On the other side, and at the same time there is what I term, cold capitalism, a brutal logic of violence, persecutions, discrimination, and racialisations in the former Eastern European space (the former Yugoslavia, Russia, and other post-Soviet countries, etc.). We saw the violence of unbelievable proportions against the LGTBIQ+ people in the former Eastern bloc, in the former Yugoslavia: beatings, killings, as well the negation of their basic human rights. We also see on a daily basis corpses floating in the sea, corpses of those who want to enter the "former" West Europe: refugees, people without papers traveling from Africa, the Middle East, and Asia, and people who have drowned along the coasts of Italy, Malta, Greece, etc., and in the last period, more and more, near Libya.

Therefore on the one side, there is the hot "former West," the once first capitalist world - that is, the Christian-capitalist patriarchal colonial and an- 
ti-Semitic regime of power - with its processes of financialisation and liberalism that goes hand in hand with inclusion in its necro capitalist (global neoliberal) though largely presented biopolitical matrix of power of all those who in the past were perceived as "others": the non-heterosexual identities (although there is still a great discrimination of trans people). To be precise, this is not about a new "enlightened logic" of the "former West" being more civilised than the former East, but a process of new racializations that on the one hand includes all those until now seen as the "others," that were discriminated in the past (the white gays and lesbians, queer as Western nation-state citizens) to produce, and, on the other hand, and at the same time, an infinite list of new Others in the West: migrants, refugees, sans-papiers, people and women of colour coming from other parts of the world, and religious backgrounds. Of course, the practices of inclusion in the West can bring the danger of reproducing homonormativity.

Global capitalism shows a new face of re-westernization and of a brutal biopolitics (managing life) that transforms into necropolitics (managing death) with invigorating precarization of the more and more class and race antagonized job market.

More, the former East of Europe is no longer post-socialist, but turbo-capitalist.

Piro Rexhepi: Post-socialist conceptual vocabularies are deeply entrenched in colonial and Cold War area studies epistemic canons. This makes it difficult to talk about coloniality in former Eastern Europe given that the dominant thinking has emerged out of Euro-American academic concerns with institutionalism, transition, and ethnographies of the socialist or Balkan "other." Katherine Verdery's analysis of her own secret service file held by the Romanian Securitate while she was a researcher there, in My Life as a Spy: Investigations in a Secret Police File, is a great example of how area studies knowledge trends are continuously adapted to an ever-narrowing Cold War binoculars to see, make, and read the world through Euro-American imaginaries where socialist era injuries are aired and appropriated to provide relief for liberal geopolitical anxieties (Verdery 2018). As Tjaša and Marina point out above, the end of socialism continues to serve the affirmation of the global ascendancy of Euro-American universalism and the need to sustain this moment is visible in the resurgent Cold War nostalgia where Russia has been resuscitated to retake its position as the convenient global Other. Critical post-socialist studies have frequently fallen prey to these nostalgic renderings of socialism, through periodizations that project pre and post-socialism as reactionary chapters of capitalism and too easily redeem socialism as the sole emancipatory possibility in between the pre and post. Nothing illustrates this better than the surge of lefty hipster flavors in the last decade roaming around post-socialist ruins searching for artifacts and antiques to trade in the post-modern marketplace and in the process discovering that socialists were people just like them. Such is the current tribute to socialist modernist archi- 
tecture from Toward a Concrete Utopia: Architecture in Yugoslavia, 1948-1980 currently on view at the Museum of Modern Art in New York where a Swiss curator reminds the viewer in a mixture of AlanDeBottonesque and TEDx fashion that lessons from Yugoslav modernist architecture could contribute to "a better life for everyone" to Ilya Khrzhanovsky's Dau.

I bring this up because I think the attraction of Western observers to socialist modernity is its propensity to emulate and respond to European and American modernity - in both style and substance but particularly in flattening, whitening and secularizing history. Like post-war Europe and the US, the socialist world laboured in producing colorblind historiography that conveniently avoided questions of colonization and racialized labor-relations unless they were deployed to forge anti-imperialist proxy wars in the post-colonies so that the centres of East and West could be violence-free. Soviet and Yugoslav global anti-racist and anti-colonial campaigns were not serious undertakings - in as much racialized populations within their borders fared no better that racialized communities under capitalism - but geopolitical techniques of conflict and cooperation between the two Cold War camps. As Jennifer Wilson has recently pointed out on the Soviet Union courting the African American intelligentsia during the Cold War, the "need to build an ideologically correct Black proletariat came before the need to understand Black literature and Black people as diverse unto themselves" (Wilson 2018). Similarly, post-colonial subjects both inside and outside the socialist worlds became tokens of global self-fashioning of the post-racial and post-colonial just as socialism developed new settler colonial regimes and methods through population displacement and modernization and urbanization of racialized people and spaces in the name of socialist progress. In this context, the socialist and post-socialist worlds have a complicated relationship to coloniality as socialist historiography disowns its racialized colonial projects but also lacks a severe assessment of its role in sustaining coloniality through a Cold War division of labour into first, second and third worlds.

From a decolonial perspective, the (post) socialist world still cannot resolve its (geo)political position of being in pact and proximity of Euro-American coloniality or its product and defying periphery. When we think of decolonial critique about the former socialist world, I believe we have to acknowledge and work with these tensions. This requires attending to erased and ongoing decolonial struggles within the (post)socialist world and their relations to larger geographies of liberation beyond area studies periodisation's, historical materialism, Eurocentric vocabularies, and imperial spatial imaginaries. More importantly, decoloniality may well be the sole political possibility to confront the post-socialist resurgence of racism now plaguing all political formations in former Eastern Europe, from left to right.

2. What characterizes Eastern European decolonial and postcolonial theory from decolonial and post-colonial theories that have 


\section{emerged from Asia and the Global South? How does Eastern Europe's socialist past influence these theories?}

Kancler: On the one hand, after the fall of the Berlin Wall in the academic system the analysis was framed into the (neo)liberal area study of Central and Eastern Europe, Postsocialist Studies, etc., while Critical Theory focused on the continuation of Marxist analysis, struggling against anti-communist rewritings of the history and present politics. On the other hand, within postcolonial studies and decolonial option, while the so-called second world vanished (even though not all communist countries were differentiated within this category, some were part of the so-called third world), former Eastern Europe was placed in Europe, as not quite white but not really colonized, rather a colonizer and racist, similar to its western counterpart, before communist/socialist and now postsocialist.

Several intents to bridge the gap through postcolonial and postsocialist dialogues, by questioning both concepts from decolonial positionality, point to the void that is characteristic of the place Eastern Europe have after the fall of the Berlin Wall in 1989. This void suggests a need for more complex analysis, which would critically address the past and present of colonialism/ imperialism's constitutive relation with capitalism and heteropatriarchy in the context of Eastern Europe, as Marina and Piro make clear in this trilogue. Since the 90s, only a few theoreticians have written extensively on this problematic and against the erasure of histories of anticolonial, antifascist and feminist struggles in former Eastern Europe. At the same time, the critical question is what socialist histories/discourses are valuable for the present struggles and, thus, need to be brought back from a vanishing communist past and its buried Marxist archives?

Rexhepi: Recent attempts to rethink post-socialist studies, societies, and subjectivities through de/coloniality and Critical Race Theory have attended to the colonial and racial entailments of pre-socialist imperial formations within socialism and post-socialism. Madina Tlostanova for instance has explored the ways in which racialization and coloniality in the Russian context are difficult to detect in part because the Russian empire, and later the Soviet Union, strove to emulate Western European capitalist imperialist discourses though this required many distortions because of Eastern Europe's own marginality within the construct of whiteness, compensating for this inferiority by projecting its caricature racism onto the newly acquired territories.

If, as Tlostanova illustrates, Russian imperialist and racialized colonial categories informed socialist and post-socialist processes of racialization, how did racialized colonial categories operate in the Balkans, where, unlike Russia, pre-socialist colonial enterprises, fragmented and fragile though they might have been, were deployed in the service of mapping out the European racial frontiers of the late $19^{\text {th }}$ and early $20^{\text {th }}$ century, which today inform the EU expansion project as an unproblematic 'unification' of Europe? 
Critical Balkan studies frequently elide colonial and racial legacies in a neutralizing critique of the Balkans as a whole being Orientalized. Todorova's Imagining the Balkans is perhaps the best example of this lumping together the Balkans into the larger category of Balkanism (Todorova 2009). Similarly, in area-studies epistemic registers the debates within the field have been mainly shaped by Western anthropologists' neo-institutionalist approach that sought to problematize the binary of socialism versus capitalism but neglected the racialization of inequalities in both contexts such as the 2011 debate between Thelen and Cullen Dunn and Verdery (Thelen 2011; Cullen Dunn and Verdery 2011). While Roma and Muslims were racialized in Eastern Europe - what does it mean that their racialization is subsumed and levelled under a broader critique of the Orientalisation of former socialist subjects? What does this erasure through levelling achieve? More importantly, who speaks in the name of the post-socialist subject? Who is taken seriously and who is dismissed as a suspect for transgressing the field's compromise around conceptual frameworks, vocabulary, subject matter to be studied and approaches? How are post-socialist racialized communities disbarred from articulating their own political agency and subjectivity vis-à-vis a scholarship that has made socialist nostalgia both colorblind and classless?

By racialized communities, I refer to those communities that have been historically marginalized by their race, not only in the broader European context but also in the context of the Balkans. I am not offering here a scientific definition of race or racialization, not only because these categories are complicated by overlapping forms of marginalization (for instance, Roma Muslims who suffer the brunt of both racism and Islamophobia), but also because "part of what's particularly productive of the racialization of the category Muslim" as De Genova (2015) points out, "is that people who are Muslim can look many different ways, so again it systematically undermines the possibility of naming race as race because it appears to only produce a culturalist discourse of difference, thereby reproducing the old-fashioned idea that you're supposed to be able to read race off the face, that you're supposed to read race off the body, that somehow race is a knowable fact of biology, that it is phenotypical and self-evident and transparent" (De Genova 2015). Race and racialization are further complicated conceptual and social registers because they do not naturally lead to intersectional solidarity, which one may assume, would naturally follow given the common histories of oppression.

Far from it, as Roma, for instance, are subject to racism from Muslim and non-Muslim groups alike, just as Serb refugees from Kosovo displaced in Serbia, who are neither Albanian nor Roma nor Muslim, are racialized as Siptari. Moreover, the racialization of migrants has allowed for almost all local racialized groups to shore up their whiteness vis-à-vis migrants. These racialized categories are therefore multivalent, complex and further complicated by ongoing neoliberal Europeanization, border-drawing, and securitization in the Balkans - all processes invested in securing the racial configuration and reproduction of 'Europe' as white and Christian/Secular. Give this, my work 
critiques the dearth of questions concerning race and coloniality within Europe, as the racialized biopolitical forms of management of populations both within and outside the EU borders intensify.

Gržinić: I distance myself entirely from recent claims that colonialism and socialism can be understood as identical. I think that engaging in macabre resentment and denigrating socialism or producing not just a critique of communism, or the populist neoliberal assaults on communism and Marxism, but to argue for capitalism as "a better option," is one of the biggest flops of decolonial thought emerging from and related to former Eastern Europe.

Take, for example, Madina Tlostanova's recent work where she develops two extremely problematic critiques. In her text "The Postcolonial and the Postsocialist a deferred coalition? Brothers forever?" (2012), Tlostanova states in an exaltation of colonial modernity that "The USSR with its showcase ideology offered a grand utopia or a new religion. The failed socialist modernity has lost its most important future vector and turned into a land of the futureless ontology. By losing to the capitalist modernity, it failed to meet the expectations of so many 'wretched of the earth'” (Tlostanova 2012). The second flop is her proposed equation of socialism and colonialism, which, I believe, is akin to equating communism and Nazism: "[Followers] of the global South are still marked by a residual sympathy towards the Soviet experiment, and socialism as such. For them, it is difficult to equate socialism with colonialism particularly that state socialism has always represented itself as an anticolonial system" (Tlostanova 2012). Both statements are problematic and show that the decolonial must be analysed in the context of global necrocapitalism.

Moreover, it is important to note that a productive critique of socialism, communism, and Marxism is necessary, especially in the context of Black people's histories of resistance. Cedric Robinson does just this in his 1983 book, Black Marxism: The Making of the Black Radical Tradition, where he confronts the Marxist analyses on one side and Black radicalism on the other (Robinson 1999a). He exposed that the later must be linked to the traditions of Africa and the unique experiences of blacks on western continents.

In an interview, given in 1999, Robinson returned to these points that should be understood as essential to discussions relating to decolonial, anti-socialist, and anti-communist positions (Robinson 1999b). He stated that in defining Black radicalism, it is crucial not to side with Black Nationalism, but to "recognize the cultural history of the enslaved" (Robinson 1999b, 6). Robinson argued that "The Black Radical Tradition is not a biological reflex, but a reconstitution of historical, cultural, and moral materials, a transcendence which both transfers and edits earlier knowledge and understandings among the several African peoples enslaved. The dialectical method is well suited to these tasks" (Robinson 1999b, 6). In this interview, Robinson was asked about Marx's belief that a communist society would emerge from the European working classes, thereby foreclosing the revolutionary potential of Black radicals throughout history despite their production of essential in- 
sights. In response, Robinson provided a fascinating answer: "What is similar [between Black radicals and revolutionaries of a similar ilk] is the historical tendency to succumb to the seductions of nationalism on the premise that Marxism is essentially Eurocentric. It is as a response to the denial of historical agency within Marx that many non-western radicals have often thrown themselves into nationalist projects" (Robinson 1999b, 7).

Robinson makes a point when asked in 1999 about his next book titled The Anthropology of Marxism: A Study of Western Socialism: "I revisit familiar sites (Hegel, Kant, Engels, etc.) only to mark forgotten and suppressed work (e.g., Hegel's study of British political economy) in order to proceed to the unexpected richness of the history of socialist visions and pursuits" (Robinson 1999b, 8).

Along with these thoughts, I can suggest that discarding the history of socialism in Eastern Europe, as asked by a part of a strand of a decolonial theory, will result in the missed opportunity to re-inscribe counter-historical experiences and practices of the social and economical and as well cultural into an insurgent path toward another future.

3. We see that capitalist political interventions in Europe increase the current political devastation. How does the history of racial and ethnic discrimination of Balkans by Western Europe inform these processes?

Rexhepi: The disintegration of Yugoslavia has served as a frequent reference point for the proponents of clashes-of-civilizations debates, which accompanied the end of the Cold War and the corresponding rise of neoliberalism. As war broke out in Bosnia, Muslims living in the Balkans, as well as the larger Muslim world, were targeted by various Islamophobic attacks, which occurred as a response to perceived threats against Euro-Atlantic geopolitical bordering projects that accompanied neoliberal reforms in the 1990s in the Balkans.

Since 9/11, 2001, Islamophobia has operated through the EU assemblages of securitization policies enacted in the European "integration" processes that seek to create and secure the EU borders in the Balkans while also labouring to privatize public wealth and subsequently integrate the Balkan labour force into the EU labour market. The borders desired by the EU thus supply Europe with both a security zone and a supply of nominally white Europeans - a racialized buffer supply zone that utilizes local race regimes and deploys them at the EU post-national level.

Kancler: The roots of the current political and economic situation in the Balkans can be traced back to the colonial/imperial capitalist history that runs over the world producing differentiations, dehumanization, and capitalist devastation. While communism/socialism intended to break with this history in terms of political and economic organization, it failed to transform the conditions of production and power relations radically. Racialization, class divisions, the oppressive gender binary, and heteronormativity were reproduced under the surface of brotherhood and unity.

In the 1990s, during the war and resulting dissolution of Yugoslavia, we started to witness a phenomenon in which capital is pushed beyond its limit, 
and through financial mechanisms, it begins to operate independently of real production. The processes of rising fascism and suspension of democracy by financial powers and the market are proposed as the "rational" and "reasonable" behaviour in the world, where through individual debt, public deficit, and public debt, the lives of entire populations are mortgaged and expropriated. According to Achille Mbembe, nation-states have become agencies for the collection of debt on behalf of global oligarchy of investors and international financial industry, which is politically unassailable (Mbembe 2011). The extortion of public debt, interests, depredation, and the expropriation of goods and common wealth rely upon accumulation, dispossession, and simultaneously occurring processes of negation and violations of human rights. Accumulation is now possible without real inversions and creation of new productive capacities, and while it works simultaneously, as Mbembe writes, through and across different scales of "race", the principal consequences include the material and existential precarity of populations or, as Judith Butler puts it, our dispensability (Butler 2011).

These transformations, as Paul B. Preciado argues, also point to the articulation of a set of new micro prosthesis devices for the control of subjectivity with new molecular biological techniques and media networks. As he writes, we are facing a new kind of capitalism that is hot, psychotropic, and punk (Preciado 2008). We must question Preciado's claim and make clear that this hot, punk capitalism operates in the "zones of being." In the contrasting "zones of non-being," we witness a cold, necrotoxic, and heavy metal capitalism (Fanon 2005). The present crisis no longer describes an exceptional period, something temporal or episodic; instead it becomes a norm, the fabric of social life and our existence. This new necropolitical mode of life, as Marina is saying, means pure abandonment. The surplus value of capital today is based and generated from (the worlds of) death.

Gržinić: Both biopolitics and necropolitics work globally. Though necropolitics' function (mostly in the so-called periphery) generating surplus-value through actual and social death, where value of life equals zero.

For example, migrant workers from former Yugoslav republics who temporarily worked in Slovenia lost their jobs, were brutally fired, and kicked out of companies and onto the streets without their wages. The so-called need for these mass firings was, in reality, the consequence of company fraud and bankruptcy. However, the repressive state apparatuses neither penalized these companies for fraud, nor the brutal infringement of workers' and human rights. Instead, the state simply deported the temporary workers to the other side of the Slovenian Schengen border, leaving them without financial compensation for their labour. This mass deportation and wage theft led to "the Erased people." 1 When we talk about the processes of exploitation, deregulation, dispossession, and racialization, we must do so in the historical context of western colonialism as well as inside the present colonial matrix of power. As stated by Achille Mbembe in his book Critique of the Black Reason, 
many people, not just Black people, are in a situation of deprivation, subjugation, exploitation. This forces them and us to think of a new condition of people in the world of global necrocapitalism that is the condition of what Mbembe calls "the becoming-negro of the world."

4. How have transition politics and the "civilizing mission" in Europe foreclosed or opened up possibilities for both non-heteronormative sexualities and gender expressions in the Balkans? What is the relation between the process of colonizing trans bodies and Eastern Europe? What is the relationship between postsocialist sexuality, Islam, and homonationalism in Eastern Europe?

Gržinić: I will re-contextualize the points made in the above question by turning to Suzana Tratnik's oral history shared in the feature-length film documentary I co-directed, Relations: 25 years of the lesbian group ŠKUC-LL. The documentary was conceived by me and Aina Šmid, along with other members of the lesbian scene surrounding ŠKUC-LL in 2012, to celebrate the $25^{\text {th }}$ anniversary of the first publicly constituted lesbian section (LL) of the Student Culture Center (ŠKUC) in 1987 Ljubljana. On the production of LGBTQ as second-class citizens through processes of violence in former Yugoslavia, and, later, in independent Slovenia, Tratnik argues:

One thing has become clear to me: that the hatred of Others was previously seen as domestic violence. It was violence against homosexuals in the parks, against homosexuals seen as second-class citizens, as less valuable people. Such violence was therefore never reported because homosexuals were ashamed. This is now very interesting to read about; a bunch of novels has appeared in the East, also a writer under a pseudonym from Belgrade, another from Poland. What was the life of gays like in the time of socialism? It was in the closet, literally in public toilets, meeting in parks, etc. In fact, when the coming out occurred, when these people were no longer satisfied with such a position, when they came out and said 'We are exactly just like you,' or, 'We are different, and we have a right to this difference and still we want to be respected,' then this violent response began. Because in the East, there was no familiarity with this type of civil movement, there was no Black Movement as there had been in America, which made the situation there completely different. There was no women's movement, as it was said in fact that it was no longer needed. All these situations, plus some ideological closures, that ruled there. Still, on the other hand, I do not want to say that the West was open. And then the presence of the war, many years of war violence, horrible killings, rapes, etc., situations that are not resolved, disastrous situations, wandering from court to court [... the result is an explosive mixture, and the situation, therefore, cannot be otherwise (ŠKUCLL 2012). ${ }^{2}$

\footnotetext{
${ }^{1}$ See https://en.wikipedia.org/wiki/The_Erased

${ }^{2}$ The whole oral history exposed in the video-film is also recontextualised in (Gržinić 2017).
} 
Achille Mbembe has provocatively asked, "But what does it mean to do violence to what is nothing?" to explain how the queer approximates physical violence that marks the edges of subjectivity itself (Mbembe 2011, 9).

Moreover, white anti-racism is increasingly acquiring a form of grandiose anti-racism that goes into the direction of self-promotion and transforms into what is termed "charitable anti-racism" that is just a different form of unreflective racism. White anti-racism is when white citizens in the Occident engage through charities in helping and sympathizing with those "Others" that are produced as Others through white capitalist state violent measures (racial profiling, denied asylum or other papers to live and work in the Occident or on the base of race produced as second and third grade citizens).

I want to emphasize that Black diaspora, migrants, and women of color (all categories which significantly overlap) have significantly influenced feminist theory to the extent that we talk presently of new-, post-, and transfeminism(s) of Color, Black feminisms and Chicana and Muslim feminisms. One of the important points in these processes of re-signifying the monolithic category of white feminism was the attack on feminism and its liaison with the regime of whiteness and capitalism. The outcome was the deconstruction of feminism with and by postcolonialism and, after 2000, with the decolonial turn of feminism (Maria Lugones).

Or, to reformulate in a politically radical way: can queer decolonial politics in Europe and globally be thought without a more precise re-elaboration of the relation between queer and the categories of nationality and race? NO! What can we then learn from the conceptualisation of queer about the nation-state, geography and processes of racialization - institutionalized, structural, and social racism(s)? A LOT!

Kancler: I think it is first necessary to challenge the basis of LGTBIQ+ activism in the West and think about what, why, and how it has been progressively absorbed into (neo)liberal politics by not addressing colonialist history, whiteness and the privilege attached to it, and the marginalization and exclusion of racialized and migrant LGTBIQ+ people. Today white, European, LGBTIQ+ politics is complicit in reproducing and maintaining the western world order, and, therefore, it is part of colonial imperialist expansionism, its wars and civilizing missions. The geopolitics of colonial capitalist time is operating by placing LGTBIQ+ as a measure of democracy, progress, and modernity, while homonationalist imaginaries and practices participate in the construction of Fortress West (Desde el Margen 2018). These hegemonic processes not only create divisions within and between gender and sexuality, but they also institutionalize the racializing differences between white LGTBIQ+ and racialized, migrants, refugee sex-gender dissidents.

A recently developed critique in the book LGBT Activism, and Europeanization of Post-Yugoslav Space interrogates a link between "Europeanisation" and "gay emancipation." The authors question the processes through which certain forms of gay activist engagement are elevated to a measure of democ- 
racy, progress, and modernity while homo-transphobic attacks are relegated to the status of non-European "Other(s)", who are inevitably positioned as appertaining to the patriarchal past that should be abandoned. As Rexhepi writes "this separation serves the purpose of creating and strengthening a local liberal European-oriented elite, which then acts as local interlocutors that, in advocating Europeanisation as the solution to violence directed toward queer communities, become vehicles of EU expansionism" (Rexhepi 2016). Therefore, if we want to consider whether transition politics have opened up possibilities for both non-heteronormative sexualities and gender expressions in the Balkans, we must first ask about its relation to a (neo)liberal conception of "liberation." We must ask for whom have these possibilities been opened, given the continued silencing and negation of past and present fights for radical liberation and self-determination by (neo)liberal capitalist colonial frames.

There are examples of theoretical, artistic, and activist work created during the last three decades in the context of former Yugoslavia, which explore the tensions between truly radical sex-gender dissident feminist practice and the (neo) liberal valorization of so-called democracy. Marina Gržinić and Aina Šmid are one of the crucial references. As members of the group Borders of Control N.4, they produced one of the first films in the former East during socialism titled Icons of Glamour, Echoes of Death (1982) and The Threat of the Future (1983). These films present and dramatize, conceptually and politically, institutions of masculinity, femininity, and lesbian relations through drag performance as well as lesbian feminist positionality. Staging a performance in front of the camera the artists spoke about sexual and gender politics, female pleasure, sadomasochism and pornography. Gržinić has continued to elaborate upon topics related to dissident feminist practices, artistic performances, and space in texts written before and after the abovementioned films (Gržinić 2008; Gržinić 2012; Gržinić 2014). In their documentary video, Relations: 25 Years of the Lesbian Group ŠKUC-LL (2012), they share testimonies of counter-power lesbian movements and their struggles for visibility and emancipation. Since the 1980s, ŠKUC-LL and its founding members Nataša Sukič, Susana Tratnik, Tatjana Greif, and Nataša Velikonja produced important analyses and engaged in political interventions that took multiple forms: texts, performances, events, and actions. Each intervention strove to redefine the very point of struggle(s) necessary to abolish discrimination in Slovenia, as well as locate the memory of the lesbian movement for a new future. The need to persistently redefine the subject of the feminist movement in Slovenia expressed itself first as a lesbian political stance. Lesbians positioned themselves in the 1990s through re-reading of history, language, and performativity, and developed a sharp critique of Western activism. They also established alliances across the (post)Yugoslav region, not only among lesbians but also with Roma, trans, sex workers, disabled activists, and other marginalized groups. In addition to this critical audio-visual production going 
back to Yugoslav Black Wave, it is also necessary to mention Želimir Žilnik's 1995 film, Marble Ass, which is the only fiction film that depicts trans practice, the subversive power of transvestite, and sex work in order to challenge nationalism at its core by disrupting the very idea of the natural, essence, and identity. Also, as Rexhepi argues in his text "From Orientalism to Homonationalism: Queer Politics, Islamophobia and Europeanisation in Kosovo," "inviting-in, disidentifications, and imperceptibility, may be just some of the living strategies "queers" use "to confront the normative liberal politics of coming out and visibility to avoid being absorbed into neoliberal governmental technologies" (Gržinić 2008; Gržinić 2012; Gržinić 2014).

Rexhepi: For nearly three decades we are witnessing what Jasbir Puar calls the folding of queer bodies into heteronormativity and modes of reproductive respectability centred on demands for rights, such as the right for gay marriage, adoption, military service, and parades (Puar 2013). LGBTQI+ movements had come to embrace the nation, nationalism, and the family by appealing for "inclusion," which bolstered these institutions during a time when the existing social structures of support were being dismantled by neoliberal economic reforms. That these trajectories overlap and inform one another is not accidental. Affective and familial economies replaced redistributive ones. Nor is it accidental that queer liberation struggles begun by queer and trans people of colour were appropriated and subsequently transformed into NGOs and civil society networks - just as liberal governmentality was transitioning into non-governmentality - whereby the delivery of social services of which the state was once responsible are now contracted out and delegated to NGOs. Like corporations that expanded their operations through former socialist markets liberalization, exploiting cheap labour and cheaper bodies, EU and US gays extended their political agendas along with myriad other industries for "saving humanity" that emerged to globalize and preach liberal humanism. All these processes are at once providing problems and solutions. Travelling gay saviours came en masse in post-socialist spaces delivering instructions for post-homophobic times. This is a disturbing trend.

The appointment of the first lesbian prime minister in the region, Ana Brnabić in Serbia under the presidency of Aleksandar Vučić who once served as an information minister in the Milosevic government is illustrative of this trend. Belgrade Pride honoured Brnabić despite her denial of Serb historical violence in Kosovo and her views on Srebrenica as not constituting genocide. Throughout the region, questions of sexuality continue to be mobilized to mediate projects and ideals of sexual rights aligned with nationalism and recognizable EU-US models of sexuality. In short, with few exceptions, LGTBIQ+ politics are still characterised by early post-socialist (homo)nationalist activism dominated by wealthy, urban, cisgender success stories of the post-socialist neoliberal reforms, disconnected and depoliticized from broader questions of social and economic justice. 
5. How to approach colonial afterlives in the EU border and integration projects imposed on the Balkans? How to confront the re-calibration of post-socialist racism? What characterizes Islamophobia in Eastern Europe? Where does the figure of the Balkan refugee stand inside capitalist humanism?

Kancler: We have to begin by recognizing that racism exists in our countries and that we are all responsible for fighting it. We must also analyse it in order to understand how local elites work together with western agents, producing the racist organization of former Eastern European space through different intertwined processes: from the imposition of neoliberal economic models, negation of labour rights, migration politics and racist methods of zoning, to pinkwashing and promoting divisions among differentiated, hierarchized and marginalized groups in terms of class, sex, gender, ethnicity, race and religion. Understanding these processes and their logic is crucial to develop effective strategies, tactics, and politics, to re-politicize solidarity, build alliances and articulate a common struggle for liberation.

Eastern European countries that became subsidiary states, peripheralised in their servile relation to EU politics, show, on the one hand, contempt toward "those below them" in processes of constant hierarchisation, and, on the other, intensified servitude toward European capitalist colonial centres. Ethno-nationalism and differentiation with labour division on a global scale are today presented as "liberation" from what was suppressed during decades of communism/socialism. European abstract universalism as a form of cosmopolitanism is counterposed to ethnonational constructions. Correspondingly, the West needs the East to project itself as a free democratic space, as a space of hospitality culture and respect for human rights, while it points to former Eastern Europe as a pathologic space, still not quite European, where racism, fascism, and homo-transphobia prevail as "essential" characteristics of the region.

By understanding racialization contextually and racism as fluid, we can say that freedom and opportunity for some is generally acquired at the expense of the "Others." Islamophobia in Eastern Europe is related to the capitalist colonial history of othering, and is present everywhere, from school textbooks to institutions, economy, politics, and everyday racism. There are continuous, systematic discriminations on religious and ethnic grounds against Muslims and Roma, which are also reproduced in the discourse of the secular left. We are trapped in what Sirin Aldbi Sibai calls "epistemological-existential, spatial-temporal and aesthetic prison" (Sibai 2012; Sibai 2017). In this context, migration is defined in terms of crisis to be managed. Calling the current reality "refugee crisis" or "migrant crisis" rather than the crisis of European politics, its capitalist economy, its systems of production of truth, its Eurocentric colonial concepts of the nation-state, citizenship, human rights, heteropatriarchy, and colonial epistemology of sex-gender binary, points to the dimension that today depoliticization has (Gržinić 2015). When 
we say "migrants" or "refugees" we must ask ourselves how are these categories being formed by hegemonic politics, through the processes of production of "Other(s)," reducing the complexity by situating migrants in the a-historic context, outside of geographic and political frames (as if EU has nothing to do with wars from where people flee) (Rodríguez 2001). At the same time, the EU migratory control apparatus regulates the selection of bodies in relation to belonging to determined ethno/national, racial, or religious groups, as well as gender and sexuality by reproducing oppressive sexual norms that are gendered, racialized, and classist.

All that was said also relates to the processes of zonification. We see that the European politics of segregation transformed former Eastern Europe into a border-zone in the way that the territory of former communist/socialist countries functions as a buffer zone to control and block migrations from Africa, Middle East and Asia, while migrants from former Eastern European countries are at the same time subjected to control, discrimination (employment), and processes of deportation from the "former" Western Europe. The democratic universality of human rights is closely related with the particular national belonging, and with whiteness. The Fortress West is strengthening borders, sophisticating exclusions and criminalization mechanisms through migration politics and institutional racism, at the same time it's accentuating the nationalist ideological mantle that deepens the ethno/racial, class, sex-gender, epistemic and spiritual hierarchies of the "otherness/externality." Likewise, in recent years we are witnessing an intensification of public discourses and attitudes of hatred that are becoming normalized, the emergence of what Philomena Essed calls "entitlement racism": the idea that majority populations have the right to offend and to humiliate the "Other." Expressions of this form of racism vary according to racial, ethnic and religious group attributions and can range from assimilative paternalism to extreme conditions of exploitation, humiliation, persecutions, racist identifications, tortures, deportations, and death (Essed 2018).

Gržinić: Today in Europe we have two modern regimes of power working at once! One is the generally accepted modern regime of power that goes from Foucault through Agamben via Butler and maybe Žižek, and is distributed in the Nato-countries in the time of crises throughout the global world; the other is the regime of colonial power. The first one functions with demanding integration and even more with the "distribution" of debts (!), fear, and fantasies, the second functions with exclusion, marginalization, de-symbolization, and disfiguration. We have, therefore, two regimes of discrimination, racialisations, and exploitations that are almost the same, but the latter is not white. Though the entanglement between them is visible in a myriad of class racialisations. Race, therefore, stands at the point of junction where sexual difference and the human resolve," as stated by Brian Carr, "into the ungendered figure of dehumanized racial 'flesh'” (Carr 1998). 
In the case of our (my proper) former Eastern Europe and now newly acquired white petit-bourgeois crippled genealogy, we have to critically conceptualize, as stated by Hortense Spillers, that "race" signals gender's socio-symbolic unmaking. Our transition from communist uncivilized nonsubjects to a capitalist, post-Cold War "not yet quite, not yet right," civilized and human subjects, (from one propriety relation to another), testifies only to our potentiality for convertibility on the capitalist market. Though it is possible to state that, as argued by Brian Carr, "white bodies are no imaginable as nonhuman because of their race as their whiteness does not have the linguistic gravity of animality, primitivity, or property," I will propose to say for us in Slovenia: white post-socialist turbo neoliberal capitalist bodies. Though it definitely remains true that, "whiteness is not enough to detect us as humans [italics added, in Carr's essay the "us" refers to the replicants from the film Blade Runner], whiteness is not 'in and of itself' a differential mark," whiteness is tediously-administratively and horrifyingly-monstrously re/produced, nurtured, and manufactured mechanism of violence, oppression, hegemony (Carr 1998).

While some are made "equal," the Others are brutally abandoned and left to die. An illustrative case is the death toll of African migrants who drowned (measured in hundreds of bodies in one single day) near the Italian island of Lampedusa. This disaster is an additional confirmation of the alarming scale of the refugee crisis in the EU. Though the most perverse situation happened afterward when Italian citizenship was given to these hundreds of dead bodies (but only so that the Italian government and the EU could bury them in Italy - it was cheaper than to send the dead bodies back to their countries of origin and to their respective families). The Italian government decided to prosecute the few who did survive as they had tried to illegally enter Italy and the EU. This is the most definite sign of the perverse and violent new attitude that Western Europe has toward human rights (after the West had been for decades heavily capitalising its democracy on it) and the occurrence of a new category of citizenship - necropolitical citizenship.

The colonial/racial division is applied to citizenship. We have two categories of citizenship: one is the category which I will name biopolitical citizenship, the EU "natural" nation-state citizens, and the other is necropolitical citizenship given to refugees and sans-papiers (paperless) after they die on EU soil. If in the hot, punk capitalism we are an oppressed group of zombified positions, all medicated and doped up, consuming sex as the only food in the time of austerity, in the cold former Eastern Europe under global capitalism we have, being beaten, and killed. Therefore, the necropolitical turn of dispossession and exploitation (part of the techno-sexual matrix of global capitalism today) teaches us entirely that neither gender nor sex is natural conditions of our lives, and neither misery, dispossession, enslavement, nor killings.

Rexhepi: The invitation to whiteness, to Euro-Atlantic structures requires not only a geopolitical separation from the racialized other but also their undoing. Like anti-Blackness and Islamophobia, which have been the 
violent canvases on which white innocence is constructed in Euro-American spaces, dehumanization, and racialization of Roma people serve to "naturalize the "hard' political borders of Europe" with Euro-American support. The recent re-enactment of socialist nostalgia is neither a solution nor socialist alternative to the colonial and racist entanglements in contemporary global politics but a recalibration of Eurocentric binary political hegemony and colonial duress of racism in the contemporary contexts. I want to hope that anti-racist and decolonial movements in the Balkans, like Vetëvendosja in Kosovo, become part of larger geographies of liberation and growing network of decolonial movements that are neither mourning the passing of socialism nor celebrating the pseudo-socialist politics of the Euro-American left but are working towards dismantling turbo-racializing capitalism and the building up of the Decolonial international.

\section{What does decoloniality mean for the Balkans both from the per- spective of geo-politics and body-politics? What will be the main traits of queer, anti-racist, decolonial, and feminist histories of feminism in Eastern Europe during and after socialism?}

Gržinić: In 2011 in the radio program "Lezbomanija” [Lesbo mania], which was hosted by Nataša Sukič on Radio Študent, Ljubljana, to reflect different histories and conditions for a politics of class, race, and gender I stated that "Before being feminists, we were lesbians." In this way, I indicated on the necessity for the persistent rearticulating of the political subject of the feminist movement, which in the 1980s in Slovenia expressed itself first as a lesbian political stance. I pointed toward a redefinition of the political subject and its history, which has become a strategic weapon in the actual social space. I proposed a redefinition of the very point of struggle for the abolition of discrimination in Slovenia.

It is clear that what global capitalism brings in front of us is a necessity to revisit globally racist, homophobic, and discriminatory processes, not as simple identity differences but as processes that are entangled with capital, new media technology and with the change of the mode of life under capital's brutal modes of racialization and exploitation. I am interested in talking about politics and interventional politics, practices, and struggles that are transfeminist, transmigrant, and politically subversive. I am interested to conceptualize the place of race, nation-State, and migrants in queer theory and global necrocapitalism, asking where they stand inside a relation of power and subjugation, saying Race Trouble: Transfeminism and Dehumanization.

I want to address two questions: 1) What do we understand as dissident feminisms? 2) How do dissident feminisms intervene in history in general and the histories of feminism in particular?

Dissident feminisms advocate for disruption of the monolithic history of feminism that is heterosexual and white and is based on a woman as the subject of feminism that is apparently a woman as a predefined biological reality (meaning based on a kind of a natural category of a woman). As such, 
dissident feminisms intervene in this history and present of monolithic feminism with positions that are marginalized causing antagonistic differentiations based on class, race, and gender. Concerning the white western world, these positions are marginalized. Moreover, these positions, that are conceptualized as minoritized consist of people being migrants and refugees or paperless from Global South and East, therefore coming from the perspective of the European Union and Austria from minoritized geopolitical sectors. These people perform jobs, which are seen as "minor" (that means that are seen simply to say as squalid within a hierarchy of a white middle class "decency") and jobs that are abusive and exploitative in terms of basic life conditions of reproduction and economic benefits.

My thesis is that today minoritized women (and here I am making reference to the title of the text "Minoritized Women Effect a Transformation in Feminism" written by Luzenir Caixeta in 2011 [reprinted 2013]) are those migrants, transgender, sex workers, lesbians, etc., who are producing a transformation in and of feminism. This implies dissident movements inside feminism that transform its white, heterosexual, essentialized contextualization of feminism (based on features that are seen as naturally appertaining to a category that is named "woman") into dissident feminisms (see that feminism is in plural!). Luzenir Caixeta, philosopher and theologian that works for maiz. Autonomous Center of and for Migrant Women in Linz, on health prevention, counselling and education of migrant sex workers, states that, [i]n recent years, a number of authors have become well known around the world who are of the opinion that the new feminism must go much further beyond the old demands of white, Western and heterosexual middle-class women for legal equality. Attention should be given to women who have always been marginalized, and the causes were leading to differentiation based on class, ethnicity and gender should be opposed (Caixeta 2013, 146). Caixeta in reference to P. Preciado argues that in opposition to a past feminism that developed its political discourse based on the division "between men (as dominators) and women (as victims), modern feminism is developing new political concepts and strategies for action that call into question what has previously been regarded as generally true: namely that the political subject of feminism [was] women - meaning women in their predefined biological reality, but especially women according to a certain notion: white, heterosexual, submissive and from the middle class" (Caixeta 2013, 146). Dissident feminisms stand in opposition "to a grey, normed and puritanical feminism, which sees in cultural, sexual or political distinctions a threat to its heterosexual and Eurocentric image of women" (Caixeta 2013, 147).

Kancler: In relation to geo-politics and body-politics, a decolonial turn with its ongoing attempt to push for a conceptual denaturalization, aims at undermining the fundamental logic of capitalism and modernity/coloniality, in need for assertion of rights (also epistemic) of the wretched. Rexhepi points out in reference to Fatima El-Tayeb's work, "in most standard academ- 
ic accounts, post-socialist Eastern Europe is perceived as white/European" (Rexhepi 2018,14). This is despite Gržinić's claim that: “In relation to 'former' Western Europe, its hegemony (supremacy) and construction of deficient 'other,' someone coming from former Eastern Europe is always part of the process of discrimination; because there is always implemented the so-called principle of the 'deficiency' of a certain geographical region called former Eastern Europe, where it is seen as such by its Western counterpart” (Kafeero et. al 2013,117). At the same time like continental Europe, racism and coloniality are occluded through categories of "class" and "ethnicity" (El-Tayeb $2011,2016)$, so when the color of the skin is a border, then, as Gržinić argues, "within the discrimination processes, we have to recontextualize ourselves, so to speak, every moment, both while entering the public as well in the private context, because it is not the same as being white and second grade, we can still hide ourselves within a system of mimicry" (Kafeero et. al 2013,117).

Feminist, Queer and Trans Studies and activism have for years faced antiracist and decolonial critiques by theoreticians and activists who focus their analysis on the coloniality of gender and articulate their interventions through the historic relations with Black, indigenous, women of color, feminisms, as well as queer of color critique, while continuously exposing the reproduction of Eurocentrism and racism by marginalizing the concerns around racialization processes, which are actually central to the capitalist colonial gender system and its logics of oppression.

The work of Maria Lugones is crucial for challenging the colonial formulation of gender classification. On the one hand, because she develops a critique of Quijano's understanding of sex as biological. She points out his failure to see that within the concept of gender the idea of sexual or biological dimorphism (man-woman dichotomy), heteronormativity, and the patriarchal distribution of power are inscribed. On the other hand, her analysis of gender within coloniality poses important questions by revealing that $\mathrm{Eu}-$ rocentrism and racism are embedded in the universal notions of the gender binary system. Lugones exposes how gender and sexual diversity are filtered through a colonizing binary gaze and presented as naturalized ideas of "sex" and "gender," both operating as Eurocentric categories. Her main claim is that the sexual difference that is itself a colonial invention (fiction), is not socialized as such. The enslaved and racialized workers, as she states, were bestialized. The concept of gender does not pick them up as men and women in a Western sense, negating their humanity and gender, while erasing the facts that in many societies and locales before the Western colonization such categorization did not exist, or categories of seniority, professional and clan principles, etc. were more important than biologized gender. Instead, as she writes, we must understand its meaning within the particular cosmology/ metaphysics (Lugones 2008). These are important statements because the traces of those histories of removal and dispossession remain, as do their entanglements in global sexual and gender politics today. As Yuderkys Espinosa, 
Diana Gómez and Karina Ochoa argue, through such analysis, the reach of her postulates is entangled with today's re-empowered critique and work already previously developed by counter-hegemonic, antiracist feminisms, which at the same time have a significant influence on the development of decolonial option (Espinosa Miñoso, Gómez Correal, and Ochoa Muñoz 2014).

If we situate the postcolonial and postsocialist dialogues within this context, we have to take into account specific features of the coloniality of gender, as Tlostanova writes, due to the erasure of socialist gender trajectories and the pre-socialist local genealogies of women and feminist struggles, as well as the multiplicity of gender expressions and dissident sexual experiences. This is related on one side with the intensified imposition after 1989 of Western feminism and Queer theory as a new kind of mind-colonization, to use Tlostanova's words, supported by grants and accompanied by particular ideological demands. On the other, it is connected to difficulties regarding a proper production of transfeminist knowledge and articulation of struggles from decolonial positionality, which would take into account a specific pre, post, and socialist experiences. Relatively scarce or entirely missing from the analysis is a sustained critical engagement with sexual and gender dissident practices, embodiment, history, and culture in the former East, with the ability to capture the systems of knowledge and experiences that exceed the categorizations of gender, sexuality and even transgender. While such discourse is yet poorly or not at all conceptualized, our condition should be regarded, as Tlostanova argues, in its complexity and dynamics with today's dispersion of former socialist subjects in different directions (Tlostanova and Kancler 2013).

To better understand our context, we should engage in what Somerville and Jasbir Puar call "reading sideways" (Somerville 2000; Puar 2017). Reading sideways means linking together seemingly unrelated and often disjunctively situated moments and their effects in ways that attend to the interconnected histories of racial, gender, sexual and other bio-necro-political formations and regulations, as well as to the practices of resistance. By shifting the geography of reason and questioning Western universalizing progressive narrative, we see that, as Espinosa Miñoso argues, "The future already was" (Espinosa Miñoso 2015, 13). In decolonial erotic turn is crucial the fact that it is the European capitalist colonial expansion, which started with the conquest of America, and by progressively introducing the first regulations and punishment laws, prohibition of homosexuality and multiplicity of gender expressions, it deployed gender and sexuality as technologies to categorize colonized subjects and organize their subsequent removal, re-education or genocides (Rodríguez Moreno 2015). Thus it is necessary to insist on the history, memory, and contribution of those voices and experiences which made a political shift, a change in perspective, and fractures in the existing system or revolution. It is important to show that today's decolonial consciousness is based and takes from previous flows of resistance to Western domination. 
Furthermore, it requires us to think about the political economy, and from which location are we speaking, to think and situate ourselves from the borderlands from where to confront and delink from the capitalist conditions of production, Eurocentric epistemology and the Western system of national identities, the classification, hierarchization and differentiation of our bodies. All this implies articulating strategies, tactics and political interventions, having in mind that decolonial revolution requires a revolutionary transformation of subjectivity, paradigms, ethics, and structures of domination. Here the critical question is how to negotiate questions of difference through the practices of solidarity and political actions to dismantle the capitalist colonial system.

Rexhepi: From an immediate and urgent point of view, I think keeping the Balkan Route open to refugees and strengthening cross-border anti-racist networks is vital to confront the rising racist politics across post-socialist spaces that have gone mainstream like the ones in Bulgaria and Croatia. Embryonic movements, like Autonomni kulturni centar Attack and Borders None in Zagreb, Legis in Skopje, SOS Team Kladuša (BiH) among others have already emerged in Salonika, Zagreb, Skopje, Belgrade and Sarajevo challenging the Euro-Atlantic geopolitical enclosure in the Balkans and forging solidarity and resistance along the route. I cannot stress the urgency of these initiatives given the electoral success of fascist coalition governments like the ones in Bulgaria and Croatia as well as the intensification racist violence and displacement of refugee and Roma communities across the Balkans. To think through a decolonial position on the post-socialist context is to refuse the EU and NATO invitation to whiteness and racial colonial-capitalist regimes labouring towards a geopolitical gated community that in sealing the Balkan refugee routes it seeks to simultaneously divide the post-socialist subject from the post-colonial subaltern other. This refusal has to be accompanied by the rebuilding of what Moten and Harney call the undercommons (Harney and Moten 2013,1). That extends from Bandung to the Balkans. I say rebuilding because despite the ongoing erasure of non-aligned solidarities of the socialist block with the post-colonial world (its problematic relations of power taken into account) histories of common struggles against racialized colonial-capitalism and coloniality offer crucial lessons for the decolonial turn. On the regional level, it means cooperative cross-border anti-racist projects that should be tied to ongoing workers movements, mobilized to prevent the privatization of whatever public and worker-run enterprises are still left from the violent post-socialist neoliberal reforms. Fundamentally, it means to detach the Balkans from Euro-Atlantic geopolitical enclosures and remake the region into a space of solidarity and resistance. This would require not only the confrontation of assembling fascist governmentalities and governments but also Balkan leftist dismissal of queer, decolonial, critical race, and Muslim studies as "identity politics" and frequently denying the contemporary and 
historical genocides on Roma, Muslim, Bosnian, and Albanian communities under the rubric of "post-socialist revisionism."

To speak about decoloniality in the post-socialist Balkan from a longer perspective, is to rethink the (post) genocidal present on our Roma and Muslim communities not as outcomes of socialism but as a historical formation of a European colonial race regime as a continuous project of violence, expulsion of undesired raced and religioned bodies and a re-conquista strategies that have sought to "make the Balkans white again" contingent on and compliant with long-dure Europeanization. This commitment to decoloniality requires a parallel undoing and unlearning of both post-socialist narratives of Europeaness as well as the constant questioning of leftist narratives that erase questions of racism, homophobia, and transphobia in nostalgic renderings of the recent socialist past as colorblind and classless. In the first instance, it means to confront the erasure of decolonial and queer struggles and memories actively hidden from plain sight in the current political projects while actively fostering and facilitation of decolonial, queer and critical race critique into post-socialist leftist communities.

Atanasoski, Neda. 2013. Humanitarian Violence: The U.S. Deployment of Diversity. Minneapolis: University of Minnesota Press.

Butler, Judith. 2011. "Fiscal Crisis or the Neo-liberal Assault on Democracy?" Critical Legal Thinking, November 14. http://criticallegalthinking.com/2011/11/14/fiscal-crisis-or-the-neo-liberal-assault-on-democracy/

Caixeta, Luzenir. 2013. "Minoritized Women Effect a Transformation in Feminism," trans. Aileen Derieg. Utopia of Alliances, Conditions of Impossibilities and the Vocabulary of Decoloniality, ed. by the Editorial Group for Writing Insurgent Genealogies, 145-148. Vienna: Löcker.

Carr, Brian. 1998. "At the Thresholds of the 'Human': Race, Psychoanalysis, and the Replication of Imperial Memory." Cultural Critique, 39 (Spring): 119-150.

Cullen Dunn, Elizabeth, and Katherine Verdery. 2011. "Dead ends in the critique of (post) socialist anthropology: Reply to Thelen." Critique of Anthropology 31(3): 251-255.

Dalal, Farhad. 2002. Race, Colour and the Process of Racialization: New Perspectives from Group Analysis, Psychoanalysis, and Sociology. New York: Brunner-Routledge.

De Genova, Nicholas. 2015. "Interview with Nicholas De Genova: The 'European' Question after Charlie Hebdo." Darkmatter: In the Ruins of Imperial Culture, October $5^{\text {th }}$. http://www.darkmatter101.org/site/2015/10/05/interview-with-nicholas-de-genova-the-"european"-question-after-charlie-hebdo/

Desde el Margen. 2018. "Manifiesto del Bloque crítico migrantas racializades putas sexo genero disidentes", Desde el Margen, June 30. http://desde-elmargen.net/ manifiesto-del-bloque-critico-migrantas-racializades-putas-sexo-genero-disidentes /

Espinosa Miñoso, Yuderkys, Diana Gómez Correal and Karina Ochoa Muñoz. 2014. Tejiendo de otro modo: Feminismo, epistemología y apuestas descoloniales en Abya Yala [Weaving from "Another World": Feminism, Epistemology and De-colonial Stakes in Abya Yala]. Popayán: Universidad del Cauca.

Espinosa Miñoso, Yuderkys. 2015. "El futuro ya fue: una crítica a la idea del progreso en las narrativas de liberación sexo genéricas y queer identitarias en Abya Yala” 
[The Future Already Was: A Critique of the Idea of Progress in the Sex-Gender and Queer Identity Liberation Narratives in Abya Yala]. Andar Erótico Decolonial, ed. by R. Moarquech Ferrera-Balanquet, 21-38. Buenos Aires: Ediciones del Signo.

Essed, Philomena. 2018. «Entitlement Racism and its Intersections: An Interview with Philomena Essed, Social Justice Scholar.» Ephemera 18 (1): 183-201.

Fanon, Frantz. 2005. The Wretched of the Earth. New York: Grove Press / Atlantic Monthly Press

Gržinić, Marina. 1996. In the Line for Virtual Bread. Time, Space, Subject and the New Media in the Year 2000, Ljubljana: ZPS.

Gržinić, Marina. 2013. "The Emergence of Political Subject," April 22, http://grzinic-smid.si/?p=1086.

Gržinić, Marina. 2008. "Former Yugoslavia, Queer, and Class Struggle." New Feminism: Worlds of Feminism, Queer and Networking Conditions, ed. by M. Gržinić and R. Reitsamer. Vienna: Loecker Erhard Verlag.

Gržinić, Marina. 2012. "Europe: Gender, Class, Race." Scholar and Feminist Online 10 (3), ed. by J. Beller. https://sfonline.barnard.edu/feminist-media-theory/europegender-class-race/.

Gržinić, Marina. 2014. "Dissident feminisms, anti-racist politics and artistic interventionist practices." P-art-icipate. Kultur Aktiv Gestalten, Mars 4. https://www.p-art-icipate.net/dissident-feminisms-anti-racist-politics-and-artistic-interventionist-practices/?pdf $=3173$

Gržinić, Marina. 2015. "100 Years of Now." German Pavillion La Biennale di Venezia. December 8. http://archiv.deutscher-pavillon.org/2015/en/.

Gržinić, Marina. 2017. "Queer, politics, racism and resistance." \#political, ed. by Jelisaveta Blagojević, Mirjana Stošić and Orli Fridman, 299-318. Belgrade: Faculty of Media and Communications.

Gržinić, Marina. 2018. Border Thinking. Disassembling Histories of Racialized Violence. Vienna, Berlin: Sternberg Press. (Publication Series of the Academy of Fine Arts Vienna, vol. 21).

Harney, Stefano, and Fred Moten. 2013. The Undercommons. Fugitive Planning \& Black Study. New York: Autonomedia.

Kafeero, Jude Sentongo, Sheri Avraham, Marina Gržinić, Marissa Lôbo, and Ivana Marjanović. 2013. "The System of Racism/White Supremacy." Utopia of Alliances, Conditions of Impossibilities and the Vocabulary of Decoloniality, 109-120. Vienna: Loecker Erhard Verlag.

Lugones, María. 2008. "Colonialidad y género: hacia un feminismo descolonial” [Coloniality and Gender: Toward a Decolonial Feminism]. Género y descolonialidad, ed. by W. Mignolo, 13-55. Buenos Aires: Del Signo.

Mabhena, Cetshwayo Zindabazezwe. 2017. "On the Colonial Matrix of Power." Sunday News, August 06. https://www.sundaynews.co.zw/on-the-colonial-matrixof-power/.

Mbembe, Achille. 2011. Necropolítica. Barcelona: Melusina.

Mignolo, Walter, ed. 2008. Género y descolonialidad [Gender and Decoloniality]. Buenos Aires: Ediciones del Signo.

Preciado, Beatriz. 2008. Testo Yonqui. Madrid: Espasa.

Preciado, Beatriz. 2016. "Ciudadanía en transición" [Citizenship in Transition]. El Estado Mental. https://elestadomental.com/especiales/cambiar-de-voz/ciudadania-en-transicion.

Puar, Jasbir. 2013. "Homonationalism As Assemblage: Viral Travels, Affective Sexualities." Jindal Global Law Review, 4 (2): 23-43. 
Puar, Jasbir. 2017. Terrorist Assemblages: Homonationalism in Queer Times. Durham: Duke University Press.

Rexhepi, Piro. 2016. "From Orientalism to Homonationalism: Queer Politics, Islamophobia and Europeanization in Kosovo." LGBT Activism and Europeanisation in Post-Yugoslav space, ed. Bojan Bilić. London: Palgrave Macmillan.

Rexhepi, Piro. 2018. Introduction to Arte-Política-Resistencia, by Tjaša Kancler, 13-18. Barcelona: Ticket Editions.

Robinson, Cedric. 1999a. Black Marxism: The Making of the Black Radical Tradition. Chapel Hill, North Carolina: University of North Carolina Press.

Robinson, Cedric. 1999b. "Capitalism, Marxism, and the Black Radical Tradition: An Interview with Cedric Robinson." Perspectives on Anarchist Theory, Spring. http:// www.cwmorse.org/archives/perspectives.on.anarchist.theory.vol3.no1.spring99.pdf

Rodríguez, Encarnación Gutiérrez. 2001. "Deconstruir la frontera o dibujar nuevos paisajes: Sobre la materialidad de lafrontera" [Deconstructing the Border or Drawing New Landscapes: on the Materiality of the Border]. Política y sociedad, 36: 85-95.

Rodríguez-Moreno, Celenis. 2017. Review: Andar Erótico Decolonial [Decolonial Erotic Walking]. Buenos Aires: Ediciones del Signo, ed. by F. Balanquet and R.Moarquech, Liminar. Estudios sociales y humanisticos. Vol. 15 № 2: 215-219.

Sibai, Sirin Adlbi. 2012. "Colonialidad, feminismo e Islam" [Coloniality, Feminism and Islam], Viento sur 122: 57-67. www.rebelion.org/docs/150680.pdf.

Sibai, Sirin Adlbi. 2017. La cárcel de feminismo. Hacia un pensamiento islamico decolonial [Prison of Feminism. Towards a Decolonial Islamic Thinking]. México D.F: Akal.

Relations: 25 Years of the Lesbian Group ŠKUC-LL. 2012. http://grzinic-smid. $\mathrm{si} / \mathrm{p}=276$.

Somerville, Siobhan. 2000. Queering the Color Line: Race and the Invention of Homosexuality in American Culture. Durham: Duke University Press.

Thelen, Tatjana. 2011. "Shortage, fuzzy property and other dead ends in the anthropological analysis of (post) socialism." Critique of Anthropology 31 (1): 43-61.

Tlostanova, Madina. 2012. "The Postcolonial and the Postsocial: A Deferred Coalition? Brothers Forever?" Postcolonial Interventions 3(1): 1-37.

Tlostanova, Madina and Kancler, Tjaša. 2013. "Post-Soviet Imaginary and Global Coloniality: A Gendered Perspective." Krontop. http://www.kronotop.org/folders/ post-soviet-imaginary- and-global-coloniality-a-gendered-perspective-madina-tlostanova/.

Todorova, Maria. 2009. Imagining the Balkans. Oxford: Oxford University Press.

Verdery, Katherine. 2018. My Life as a Spy: Investigations in a Secret Police File. Durham: Duke University Press.

Wilson, Jennifer. 2018. "The Soviet Anthology of 'Negro Poetry'” The Paris Review, May 15. https://www.theparisreview.org/blog/2018/05/15/the-soviet-anthology-of-negro-poetry/ 